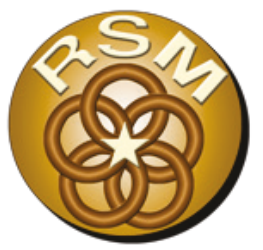

\title{
Reservoir Sediment Management Workshop for Regulators, Planners, and Managers
}

\author{
by John Shelley, Paul Boyd, Travis Dahl, lan Floyd, \\ and Marielys Ramos-Villanueva
}

PURPOSE: This Regional Sediment Management Technical Note (RSM-TN) summarizes a training workshop held on the topic of reservoir sediment management supported by the U.S. Army Corps of Engineers (USACE), National RSM Program, RSM-University (RSM-U) series of workshops. The workshop included 3 days of training on reservoir sedimentation impacts and sediment management strategies with a specific focus on regulators, planners, and managers.

INTRODUCTION: Most sediment detention dams in the United States were designed to trap and store sediment over a pre-determined sediment design life of 50 to 100 years. Over half of the USACE dams have now passed their 50-year life, and the need for sediment management is becoming more evident. The old strategy to trap and store sediment while starving downstream channels is not sustainable and will lead to both a dramatic increase in operations and maintenance costs and an eventual complete loss of reservoir benefits. Reservoir sediment management is a necessity to sustain the level of benefits initially provided by these reservoirs. Regulators, planners, and managers need to be prepared to make informed decisions about reservoir sediment management activities.

On 15-17 August 2017, the RSM Program facilitated a training workshop at the USACE Risk Management Center in Lakewood, CO, on reservoir sediment management, with a specific focus on topics of interest to regulators, planners, and managers. Thirty-six people attended, with robust participation by 14 USACE districts and research laboratories. Other participants included the U.S. Bureau of Reclamation (USBR), Denver Water, the Kansas Water Office, Electric Power Research Institute (a hydropower industry group), Brigham Young University, and reservoir sedimentation experts Dr. George Annandale and Dr. Rollin Hotchkiss.

WORKSHOP AGENDA: The workshop focused on the big picture, including the need for reservoirs, impacts of reservoir sediment accumulation, an array of potential solutions, screening methods for sediment management options, environmental implications of both doing nothing and of implementing sediment management strategies, and the regulatory process. The workshop included training lectures by USACE and invited subject-matter experts as well as presentations on case studies (Figure 1), hands-on demonstrations, a tour of the USBR physical model facilities, and a site visit to the Cherry Creek Dam and downstream channel. Internationally known reservoir experts Drs. Annandale and Hotchkiss provided additional lectures, and Cara Hendricks (Kansas Water Office), Susan Nall (USACE Sacramento District [SPK]), and Ben Wilson (SPK) presented additional case studies. The workshop extended over 3 days, as presented in the following agenda. PowerPoint presentations are available at the RSM website: https://rsm.usace.army.mil. 
ERDC/TN RSM-18-7

July 2018

\section{Tuesday Session}

Making the Problem Real (Dr. John Shelley, USACE Kansas City District [NWK])

The Regional Sediment Management Program (Linda Lillycrop, U.S. Army Engineer Research and Development Center [ERDC], Coastal and Hydraulics Laboratory [CHL])

The Future Without Project for Reservoirs (Dr. John Shelley, USACE-NWK)

Sustainable Water Supply (Dr. George Annandale, George W. Annandale, Inc.)

Reservoir Benefits (Travis Dahl, USACE-ERDC-CHL)

The National Perspective (Dr. Paul Boyd, USACE Omaha District [NWO])

Sediment Sources (Travis Dahl, USACE-ERDC-CHL)

Reservoir Sediment Mechanics (Ian Floyd, USACE-ERDC-CHL)

Physical Modeling: Bureau of Reclamation Lab Demonstrations

Wednesday Session

Measuring Reservoir Sedimentation (Travis Dahl, USACE-ERDC-CHL)

Reservoir Sedimentation Problems 1: Lost Benefits, Operability, and Dam Safety Concerns (Dr. John Shelley, USACE-NWK)

Reservoir Sedimentation Problems 2: Upstream Channel Effects (Dr. Paul Boyd, USACE-NWO)

Reservoir Sedimentation Problems 3: Downstream Channel Effects (Travis Dahl, USACE-ERDC-CHL)

Reservoir Sediment Management 1: Reducing Incoming Sediment Load (Ian Floyd, USACE-ERDC-CHL)

Reservoir Sediment Management 2: Responding to Sedimentation Impacts (Dr. Paul Boyd, USACE-NWO)

Reservoir Sediment Management Case Study: John Redmond-- Dredging with Land Disposal (Kara Hendricks,

Kansas Water Office)

Reservoir Sediment Management 3: Actions for Long-Term Sustainability (Dr. John Shelley, USACE-NWK)

Reservoir Sediment Management 4: Density Current Venting (Marielys Ramos-Villanueva, USACE-ERDC-CHL)

Hands-On Bucket-and-Sand Demonstrations of Sediment Management Methods

Reservoir Sediment Management Case Study: Millsite Dam - Dredging with Downstream Discharge of Sediments

(Dr. Rollin Hotchkiss, Brigham Young University)

Screening Level Analyses of Sediment Management Methods (Dr. Paul Boyd, USACE-NWO)

Modeling Analyses of Sediment Management Methods (Ian Floyd, USACE-ERDC-CHL)

Discussion: Who Pays for the Sins of the Watershed? (Dr. John Shelley, USACE-NWK)

\section{Thursday Session}

Downstream Impacts of Reservoir Sediment Management (Dr. John Shelley, USACE-NWK)

European Laws and Regulations for Reservoir Sediment Management (Dr. Rollin Hotchkiss, Brigham Young

University)

USACE Regulatory Process: RGL 05-04 (Susan Nall, USACE Sacramento District [SPK])

Regulatory Case Study 1: Kannapolis Lake (Dr. John Shelley, USACE-NWK)

Regulatory Case Study 2: Cherry Creek (Dr. Paul Boyd, USACE-NWO)

Regulatory Case Study 3: Fall Creek (Dr. Paul Boyd, USACE-NWO)

Regulatory Case Study 4: Spencer Dam (Dr. Paul Boyd, USACE-NWO)

Regulatory Case Study 5: Paonia Reservoir (Benjamin Wilson, USACE-SPK)

Regulatory Case Study 6: Millsite Dam (Dr. Rollin Hotchkiss, Brigham Young University)

Breakout Groups: Developing Permitting Questions and Conditions

Presentations of Breakout Group Responses

Workshop Evaluation and Feedback Form

Site Visit to Cherry Creek 


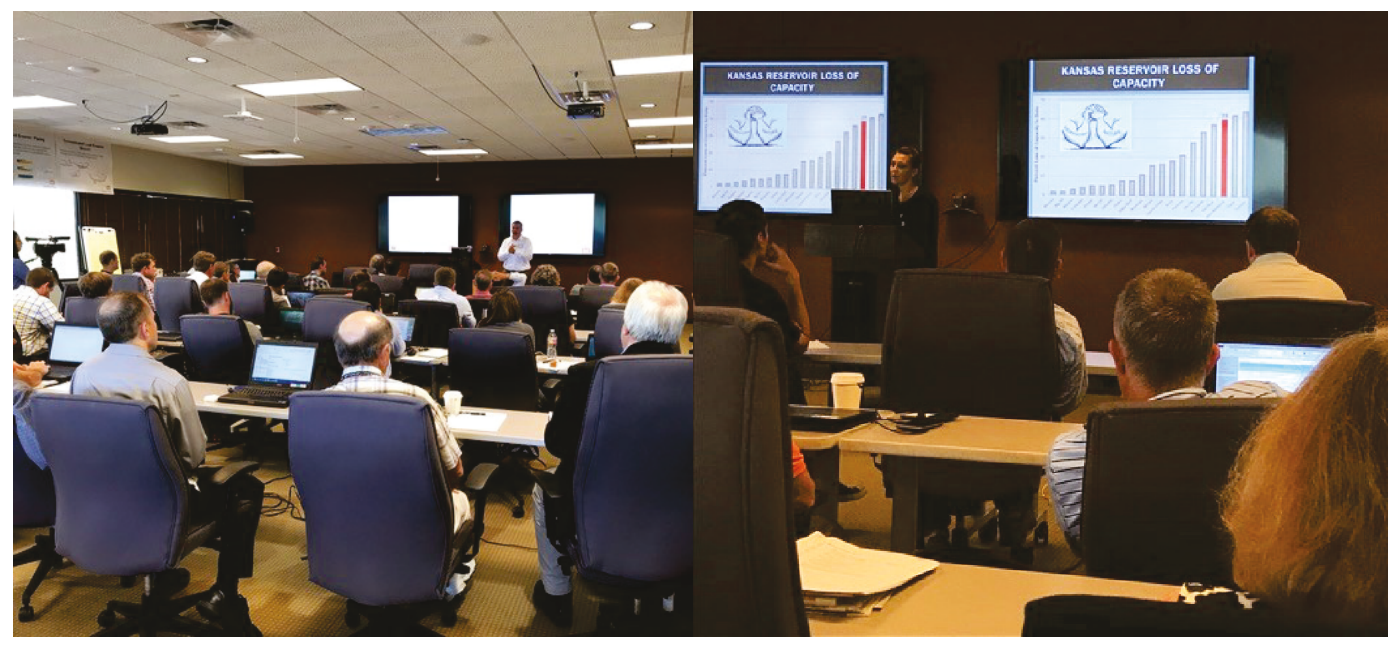

Figure 1. Training presentations.

SEDIMENT MANAGEMENT AND REGULATORY CASE STUDIES: In addition to the numerous examples provided in the training lectures, participants benefitted from the presentation of three detailed case studies: (1) the John Redmond Dredging Project (Cara Hendricks, Kansas Water Office), (2) the Millsite Lake Dredging Project (Rollin Hotchkiss, Brigham Young University), and (3) the Paonia Reservoir drawdown (Susan Noll and Benjamin Wilson, USACESPK). Additional information is available in the PowerPoint slides, available at https://rsm.usace.army.mil.

John Redmond Dredging Project. The John Redmond Dredging Project, located in central Kansas, included the dredging of 3 million cubic yards $\left(\mathrm{yd}^{3}\right)$ of sediment by the State of Kansas at a cost of approximately $\$ 6.70 / \mathrm{yd}^{3}$ or $\$ 20$ million total. This project represents the first major dredging project on a USACE lake by a non-federal entity. The Kansas Water Office was required to secure eight permits, including Section 408 permission and a Section 404 permit from the USACE. The dredged sediments were discharged into confined disposal facilities (CDFs) downstream from the dam (Figure 2). The project successfully removed approximately 3 -years' worth of accumulated sediment, with the project cost financed over 15 years. As a longterm strategy, dredging with disposal of sediments into CDFs is too expensive and requires too much land to be viable at this reservoir. The same will be true for most reservoirs. For these reasons, reservoir dredging with sediment disposal into CDFs is rare internationally.

Millsite Lake Dredging Project. Millsite Lake is a non-federal reservoir in rural Utah that recently acquired a USACE permit for reservoir sediment management. Rather than pumping dredged sediments into CDFs, the Millsite Lake dredging project discharges the sediment into the downstream channel for a significant cost savings (Figure 3). This activity was viewed as a restoration activity by state environmental agencies, as the downstream channel was degraded and ecologically impaired from a lack of sediment. Despite this, the action took 2 years to permit, due in part to the USACE Regulatory Office's unfamiliarity with reservoir sedimentation issues and in part due to the applicant's unfamiliarity with the USACE permitting process. 

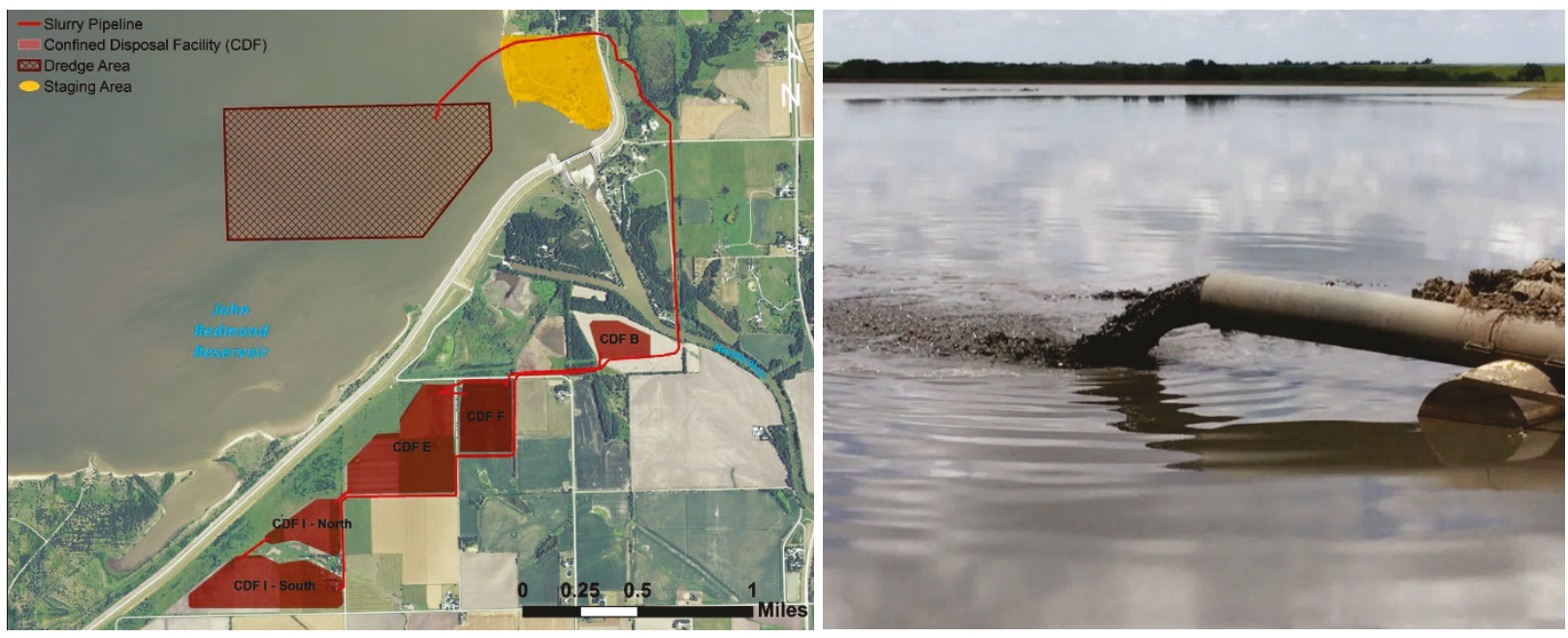

Figure 2. Diagram of John Redmond dredging project (left) and the dredge discharge pipe into CDF E (right).

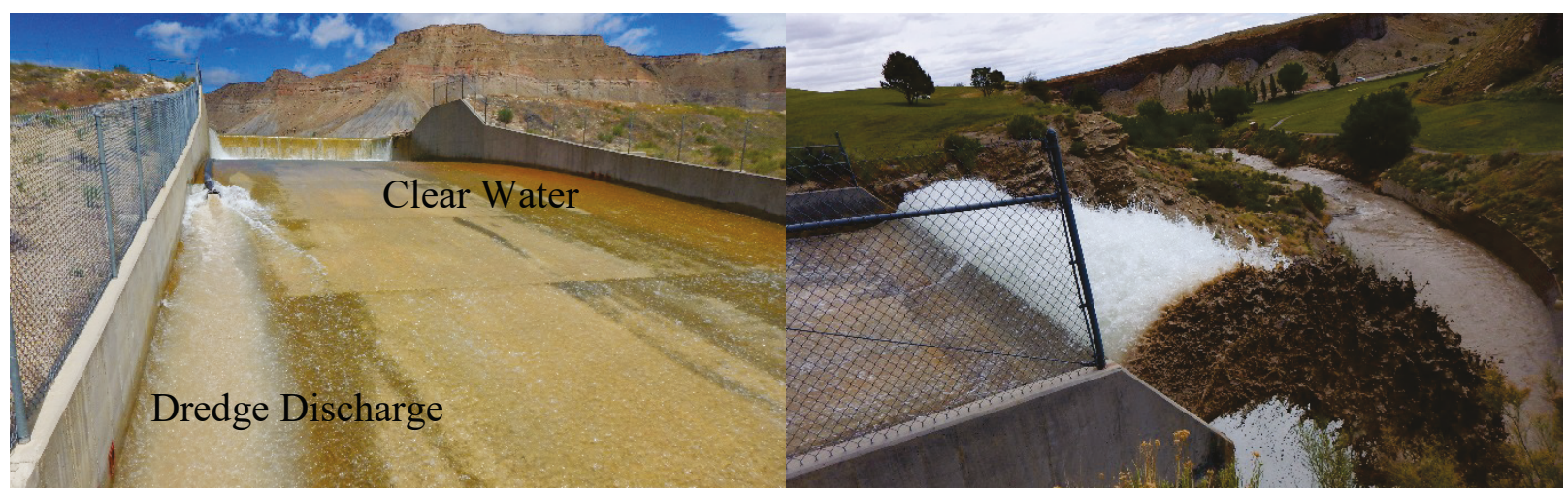

Figure 3. Spillway discharge from Millsite Reservoir (June 2017). The dredge discharge induces the turbid plume.

Paonia Reservoir Drawdown. Paonia Reservoir is a USBR reservoir in western Colorado. Sediment had accumulated in the reservoir since closure in 1962, resulting in a reservoir $25 \%$ full of sediment by 2014. More problematic than the total storage loss was the location of the deposited sediments. By 2014, the sediments had completely blocked the water intake structure (Figure 4).

In 2016, the USBR conducted a drawdown, in which the pool was drained and the reservoir allowed to flow like a river for 23 days. During this time, massive quantities of sediment were flushed downstream. Drawdown flushes of this type are often the least expensive means to remove sediment from reservoirs, though the high sediment loads discharged in a concentrated time frame can negatively impact fish in the downstream channel. Drawdown flushing is the most common method for reservoir sediment management worldwide, particularly in small reservoirs. 

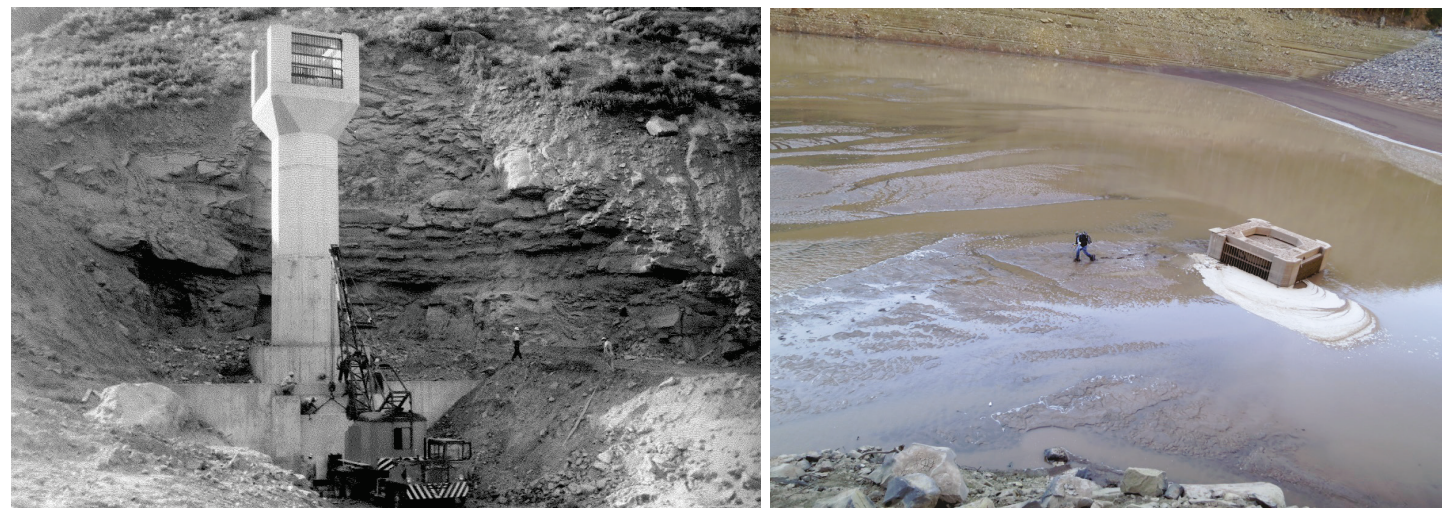

Figure 4. Paonia Reservoir Inlet in 1961 (left) and 2014 (right). Note the individual walking on the sediment in the 2014 picture.

The USACE Regulatory Office became involved after receiving complaints of fish kills from land owners and anglers downstream. The USBR was subsequently required to apply for and receive a USACE permit before repeating the flush (scheduled for December 2017). See the presentation Downstream Impacts of Reservoir Sediment Management, available at https://rsm.usace.army.mil, for more information on how to minimize negative environmental effects from flushing.

These case studies represent just three examples of reservoir sediment management. Numerous methods for reservoir sediment management have been successfully applied at reservoirs around the world. The most cost-effective and environmentally appropriate option for a given reservoir and river system depends on site-specific considerations.

\section{HANDS-ON DEMONSTRATION, LABORATORY TOUR, AND PROJECT SITE VISIT:} Participants experienced reservoir sediment management hands-on with small-scale bucket-andsand demonstrations. Participants were able to get their hands dirty while gaining appreciation for how dredging, hydrosuction, inlet extension, and drawdown flushing actually work.

Connie Svoboda and Kit Shupe, hydraulic engineers with the USBR, led the participants on a tour of the USBR Hydraulics Laboratory physical model facilities at the Denver Federal Center. Participants saw examples of how physical modeling can be used to answer dam and reservoir questions (Figure 5).

The workshop concluded with a site visit to Cherry Creek Lake (Figure 6). Cherry Creek Lake manages sediment that accumulates at the gates with an annual pressure flush. A pressure flush is a maintenance activity, not a long-term sediment management strategy, because it only removes sediment from the immediate vicinity of the gates. The annual pressure flush at Cherry Creek Lake occurred 2 months prior to the workshop. At the site visit, participants were able to see the incision in the downstream channel caused by the sediment trapping in the reservoir. Adverse weather prevented touring the control tower. 


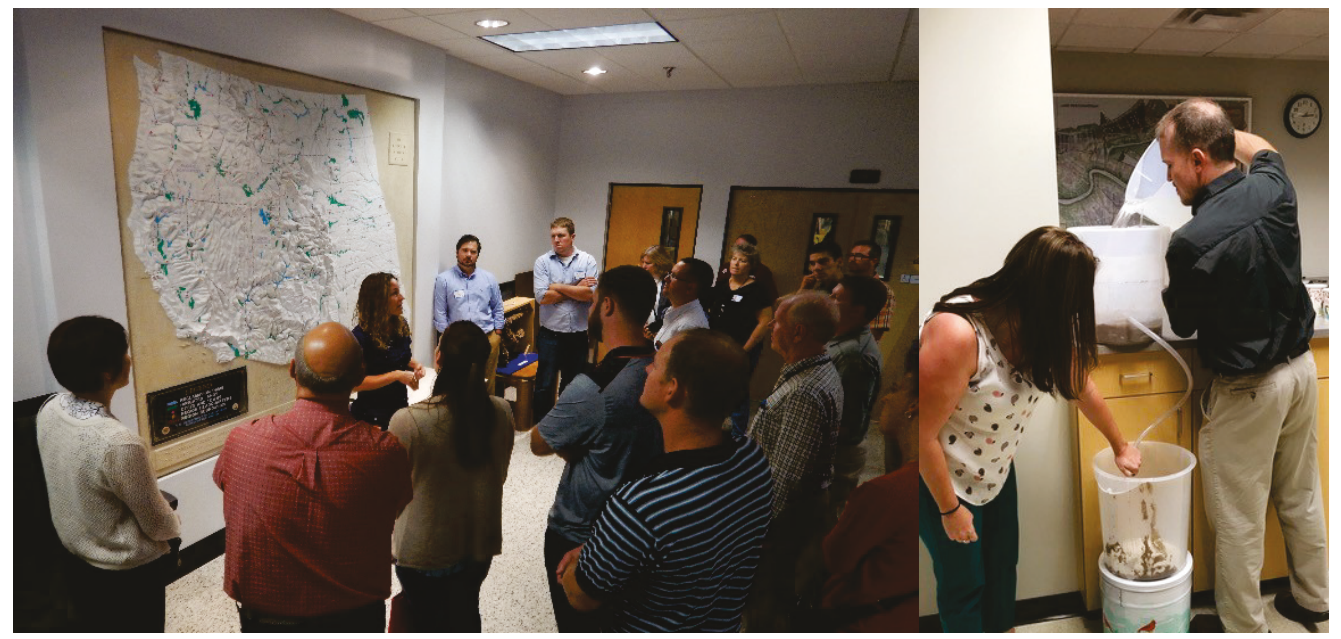

Figure 5. USBR laboratory tour (left) and hands-on demonstrations (right).

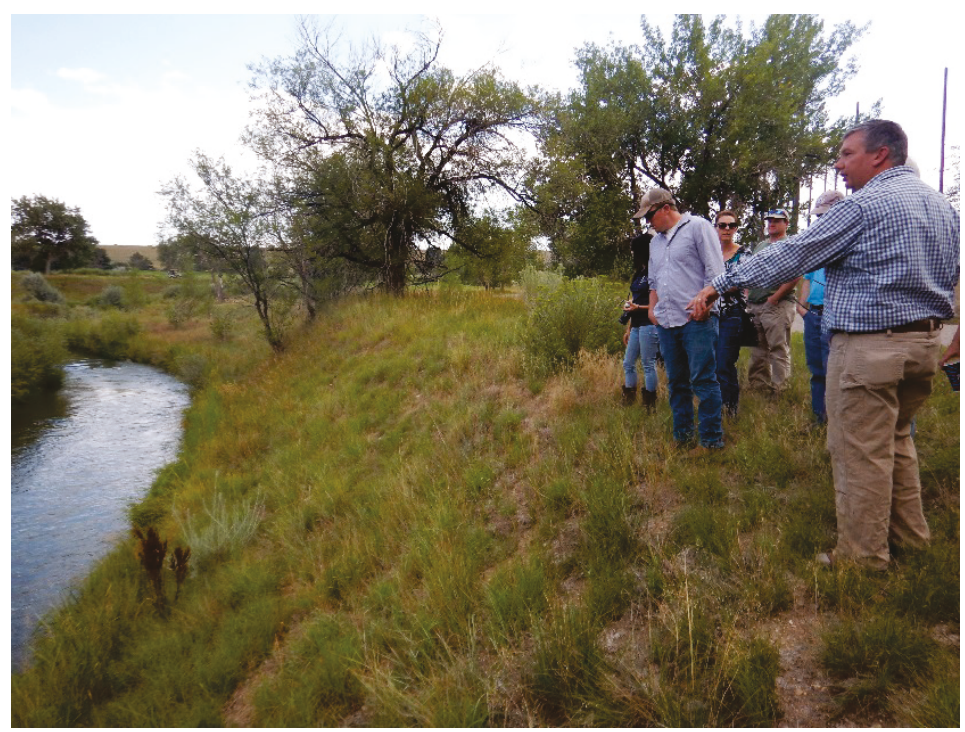

Figure 6. Site visit to Cherry Creek Lake.

FEEDBACK AND SUGGESTIONS: This section summarizes feedback from workshop participants.

Knowledge Self-Assessment: How Would You Rate Your Knowledge of Reservoir Sedimentation Issues before and after the Workshop? Participants arrived at the workshop with varying levels of background on reservoirs and reservoir sedimentation, yet all responded that their knowledge increased (Figure 7). The average score rose from 4 to 7.5 . 


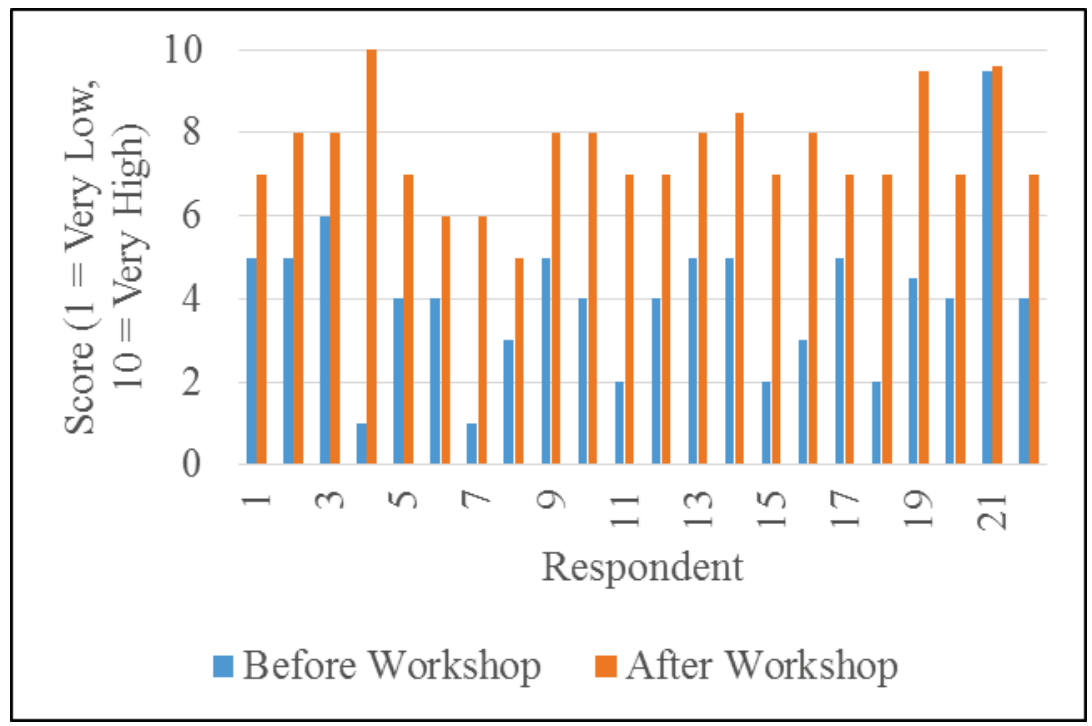

Figure 7. Self-assessment of knowledge of reservoir sedimentation issues before and after attending the workshop.

Teaching Effectiveness. Participants felt like the major themes of the workshop were effectively taught. Table 1 lists answers to the question "On a scale of 1 (worst) to 10 (best), how well did the workshop convey/explain the following?"

\section{Table 1. Participants' Feedback on the Effectiveness of the Workshop at Conveying/Explaining Major Themes}

\begin{tabular}{|c|c|c|c|c|}
\hline & $\begin{array}{l}\text { Importance } \\
\text { of Reservoir } \\
\text { Functions }\end{array}$ & $\begin{array}{c}\text { Problems } \\
\text { Associated with } \\
\text { Reservoir } \\
\text { Sedimentation }\end{array}$ & $\begin{array}{l}\text { Available Methods for } \\
\text { Managing Reservoir } \\
\text { Sediment }\end{array}$ & $\begin{array}{c}\text { Environmental } \\
\text { Considerations for } \\
\text { Reservoir Sediment } \\
\text { Management }\end{array}$ \\
\hline $\begin{array}{l}\text { Number of } \\
\text { Respondents }\end{array}$ & 22 & 22 & 22 & 22 \\
\hline Minimum & 6 & 7 & 6 & 4 \\
\hline Maximum & 10 & 10 & 10 & 10 \\
\hline Mean & 8.7 & 9.2 & 8.8 & 8.0 \\
\hline
\end{tabular}

What Needed More Time? Participants' written responses to the question "What needed more time?" included requests for information on the cost/benefit analysis for reservoir sediment management, environmental impacts, more case studies that include the National Environmental Policy Act documentation, dredging, example sediment management plans, an example game plan for implementation, how to start policy-level discussions on overcoming regulatory obstacles, reservoir sediment management vs. dam removal, and how to utilize the RSM program for assistance with reservoir sediment management.

What Needed Less Time? Several participants felt that too much time was spent on numerical modeling. While only one presentation was given on numerical modeling, the technical detail of the presentation could be better tailored for the non-engineer audience. 
Other Feedback. In Fiscal Year 18, the RSM program will hold a second workshop focusing on the technical aspects of reservoir sediment management for engineers. However, several workshop participants expressed a desire for the workshop for planners, regulators, and managers to be repeated for co-workers and colleagues. Additional workshops for local regulatory personnel in various regions will be considered. Other participants indicated that more U.S. case studies are needed. This highlights the ongoing need for pilot projects utilizing different management strategies and the need to further document existing reservoirs with sediment management actions.

CONCLUSION: The RSM-U Reservoir Sediment Management training workshop held 15-17 August 2017 at the USACE Risk Management Center, Lakewood, CO, was highly successful in educating a group of regulators, planners, and managers about reservoir sediment management. The workshop included presentations, case studies, hands-on demonstrations, and laboratory and field site visits. Given the widespread nature of the challenges with reservoir sedimentation, additional workshops are recommended.

ADDITIONAL INFORMATION: This RSM-TN was prepared by Dr. John Shelley, hydraulic engineer, USACE Kansas City District (NWK); Dr. Paul Boyd, hydraulic engineer, USACE Omaha District (NWO); Travis Dahl, research hydraulic engineer, and Ian Floyd, research physical scientist, and Marielys Ramos-Villanueva, research hydraulic engineer, U.S. Army Engineer Research and Development Center, Coastal and Hydraulics Laboratory (ERDC-CHL). The study was conducted as an activity of the USACE National Regional Sediment Management (RSM) Program, a Navigation Research, Development, and Technology (RD\&T) portfolio program administered by Headquarters, USACE. For information on the RSM Program, please consult http://rsm.usace.army.mil or contact the USACE National RSM Program Manager, Ms. Linda Lillycrop, Linda.S.Lillycrop@,usace.army.mil. For information regarding this RSMTN, please contact John Shelley,john.shelley@usace.army.mil.

This Regional Sediment Management Technical Note (RSM-TN) should be cited as follows:

Shelley, J., P. Boyd, T. Dahl, I. Floyd, and M. Ramos-Villanueva. 2018. Reservoir Sediment Management Workshop for Regulators, Planners, and Managers. ERDC/TN RSM-18-7. Vicksburg, MS: U.S. Army Engineer Research and Development Center. http://dx.doi.org/10.21079/11681/27926.

NOTE: The contents of this technical note are not to be used for advertising, publication, or promotional purposes. Citation of trade names does not constitute an official endorsement or approval of the use of such products. 